\title{
ICT in National Pandemic: The Hope for Academic Development (Case Study of Secondary Schools and Universities in Owerri Municipal Nigeria)
}

\author{
Ihenetu Stanley Chukwuemeka* \\ Faculty of Science, Imo state university owerri, Nigeria, P.O. Box, 2000 \\ Dr. Ibe Francis Chizoruo \\ Faculty of science, Imo state university owerri, Nigeria, P.O. Box, 2000 \\ Echendu Lilian \\ Faculty of Education, University of Port Harcourt, River state Nigeria, PMB 5323 Choba
}

\begin{abstract}
Information and communication technologies (ICT) have become more of a classroom to all nation in carrying out academic activities. This research work used descriptive research method of analysis. This study was concerned with looking at the significance and hope of nations through the use of ICT in academic development in secondary and university education in Owerri municipal Imo state, Nigeria. Out of the Two hundred and five (205) respondent used for this research from different schools, including teachers the majority of respondents $132(64.4 \%)$ were females and the remaining $73(35.6 \%)$ were males. Their ages were $73(36 \%)$ for 16-20 years, $61(30 \%)$ for 10 15 years, $51(26 \%)$ for $20-25$ years and $17(8 \%)$ for 26 years above. All the 205 respondents indicated that ICT is the only hope for distance learning during national pandemic for academic development. The researcher went further to ask the respondents the frequently used ICT software that aids online learning and the highest respond shown that whatsapp (50\%) was the highest used app due to its ability to reduce data consumption followed by Google classroom (24\%). They found out that the use of ICT encourage research activities since all information needed for any form of online research is found on the internet. Majority of the respondents strongly agreed that ICT permits online assignment (57.5\%). Communicating high expectations, emphasizing time on task, creating quizzes and exams, immediate feedback mechanisms are major principles underlying teaching. This research can conclude that ICTs are said to help expand approach to education, support the relevance of education to the progressively digital workplace, and raise educational quality.
\end{abstract}

Keywords: academic, ICT, national, pandemic

DOI: $10.7176 / \mathrm{IKM} / 10-7-02$

Publication date:October $31^{\text {st }} 2020$

\section{Introduction}

According to Daniels (2002) ICTs have developed within a precise short time, the major and the basic building blocks of contemporary society. All countries, nations, cities and even villages now embrace ICT as the key factor in learning and in medical fields with the basic understanding and mastering the elementary skills and perceptions of ICT as part of the fundamental of education, alongside reading, writing and proficiency. However, when the word ICT is mentioned, people only refer to it as generally 'computers and computing related activities'. This is providentially not the case, although computers and their application have significantly play a substantial role in modern information management, other technologies and/or systems also comprise of the phenomenon that is commonly regarded as ICTs. Pelgrum and Law (2003) state that near the end of the 1980s, the word 'computers' was exchanged by 'IT' (information technology) indicating a shift of focus from computing technology to the capacity to store and retrieve information. This was accompanied by the introduction of the term 'ICT' (information and communication technology) within 1992, when e-mail started to become accessible to the general society at large (Pelgrum and Law, 2003). According to a United Nations report (2001) ICTs comprise libraries and documentation centres, Internet, network-based information services, service provision, information technology equipment and services, telecommunications equipment and services, media and broadcasting, commercial information providers, and other related information and communication activities. According to UNESCO (2002) information and communication technology (ICT) may be regarded as the combination of 'Informatics technology' with other related technology, precisely communication technology. The numerous kinds of ICT products accessible and having relevance to education, such as audio conferencing, interactive voice response system, radio broadcasts, teleconferencing, email, television lessons, interactive radio counselling, CD ROMs and audiocassettes etc have been used in education for different purposes (Sharma, 2003; Sanyal, 2001; Bhattacharya and Sharma, 2007).

ICTs have the potential to revolutionize, accelerate, supplement, and deepen skills, to encourage and engage 
students, to help relate school experience to work exercises, create economic viability for tomorrow's workers, as well as strengthening teaching and helping schools change (Yusuf, 2005). As Jhurree (2005) states, much has been said and reported about the impact of technology, especially computers, in education. Initially computers were basically used for teaching computer programming but the development of the microprocessor in the early 1970s saw the introduction of inexpensive microcomputers into schools at a speedy rate. Computers and applications of technology became more pervasive in society which led to a disquiet about the need for computing skills in everyday life. Hepp et al., (2004) claim in their paper "Technology in Schools: Education, ICT and the Knowledge Society" that ICTs have been employed in education ever since their inception, but they have not always been massively present especially in the rural areas. Though at that time computers and other ICT related materials have not been fully integrated in the learning of traditional subject matter both outside the classroom and inside the classroom situations, the commonly accepted rhetoric that education systems would need to groom citizens for lifelong learning in an information society enhanced interest in ICTs (Pelgrum and Law, 2003). The impression that teaching and learning can successfully take place by means of technology stimulates both hope and dismay. There is the hope that more learners can be accomplished at a more convenient pace than has previously been the case, dismay that the infrastructures necessary for deploying technological resources or forming an effective ICT platform are lacking in low-income countries. Tella et al. (2007) examined Nigerian secondary school teachers' uses of ICTs and its implications for further development of ICT use in schools through a census of 700 teachers. The results showed that for teachers a lack of technical support in the schools and teachers' lack of expertise in using ICT were the prominent factors hindering teachers' readiness and confidence of using ICT during lessons. Teachers are not continuously fully aware that pedagogic uses of the computer necessitate the development, among teachers as well as students, of new skills and attitudes for the effective use of ICT. Aside from computer/digital literacy, teachers see ICT as sparking interest in students in the subject and in learning and an attitude towards information technology as a learning tool as an essential part of a lifelong interest in learning. Building on this, it becomes clear that ICT must be linked to the specific needs of developing countries and cease from the 'one size fits all' approach (Leach 2005) with ICT being used as a learner-centered tool, instead of within the more traditional pedagogy (Liverpool, 2002).

Pandemics are for the most part disease outbreaks that become widespread as a result of the spread of humanto-human infection (Maurice, 2016). There have been many significant disease outbreaks and pandemics recorded in history, including Spanish Flu, Hong Kong Flu, SARS, H7N9, Ebola, Zika (WHO, 2011, Rewar et al., 2015) and recently Corona virus which is also known as COVID-19, which the outbreak came like a short in 2019 making the recent national pandemic. Most people infected with the COVID-19 virus will experience mild to moderate respiratory illness and recover without requiring special treatment. The term "pandemic" has not been defined by many medical texts, but there are some key descriptions of a pandemic, including high attack rates and explosiveness, wide geographic extension, disease movement, novelty, severity, minimal population immunity, infectiousness and contagiousness, which help us to understand the concept better, if we examine similarities and differences among them. The pandemic related emergencies have been associated with enormous negative impacts on health, economy, society and security of national and global communities. As well, they have caused significant political and social disruption (WHO, 2011).

Over the past years there are studies that link to the importance of the use of ICT in various academic and health organization. The main interest, motivation and problem of this study therefor is to investigate the significance of ICT in academic development to a national pandemic in secondary schools and universities in Owerri municipal Imo state; case study of selected schools in Owerri municipal. Considerable attempts may have been made at researching on some variables or factors affecting the use of ICT (Gaskell and Tait, 2003), but this research work moved to explore the significance and roles of ICT in the midst of national pandemic. Overall, it is contended that distance learning models, delivered through the use of new ICTs, have a large amount to offer in overcoming problems in the education systems of African countries and the world at large (Grace and Kenny, 2003; Gaskell and Tait, 2003). Perraton (2000) suggests that distance education can be used efficiently and successfully for all four main aspects of teacher training: providing trainee teachers with a general education knowledge; improving their knowledge of the subjects they will teach using ICTs; teaching them about children, the curriculum and pedagogy; and developing their classroom skills both in physical classroom and distance learning classroom for the sake of distance learning (Perraton, 2000).

This study is concerned with looking at the significance and hope of nations through the use of ICT in academic development in secondary and university education in Owerri municipal Imo state, Nigeria. In order to achieve this, this study will do the following:

1. Explain the concept of ICT in education and national pandemic

2. Conclude what roles and significance ICT can play in academic activities development

3. Determine the basic awareness, knowledge and skills teachers and students have that are necessary for participation in the use of ICT in schools and homes during national pandemic.

The significance of this study lies on two different areas; the state government and the school authorities. As 
known by all educators, the teachers plays the major significant role in formation of a child's personality, socialization and community development through their verse knowledge in learning and psychological training using various methods but most teachers are not acquainted with ICT knowledge and principles because of their regular physical classroom methods. If the concern of education, in particular is to inculcate knowledge to the child using any method and even outside the classroom, then this research work shall be of great importance to parents, school children, educators and the nation. The major significance of this study are listed below;

1. Government: the findings of this study would help the federal, state and local government communities to know the importance of ICT in schools and during national pandemic.

1 School authorities: the findings also would be of great help to the school authorities to know how the values and relevance of ICT in development of academic setups in schools.

The use of ICT in educational settings, by itself acts as a catalyst for change in this domain. ICTs by their very nature are tools that promote and support self-sufficient learning and distance learning as well. Students using ICTs for learning purposes become submerged in the process of learning and as more and more students use computers as information sources and cognitive tools, the influence of the technology on supporting how students learn will continue to increase. This is fortunately not the case, although computers and their application play a significant role in modern information management, other technologies and/or systems also encompass of the phenomenon that is commonly regarded as ICTs. There are many attempts (UNESCO, 2002), to establish the general set of principles that need to be in place for ICTs to be used effectively in teacher training. The emphasis is primarily placed on the necessity for teachers first to be trained in basic ICT skills so that distance learning can be encouraged even in the presence of national pandemic. Emanating from the main research problem, namely ICT in national pandemic for academic development in schools has the following research questions:

1. What is ICT?

2. Why should students and teachers be encouraged to use ICT?

3. What roles can ICT play in academic development during national pandemic?

The conceptual framework is a set of coherent ideas and concepts organized in a manner that makes them easy to communicate. Uwaifo (2006) defines conceptual framework as a streamlined representation of an empirical situation of phenomenon. The model for conceptual framework of this study was adapted from (Whitemarsh, 2008) on the relationship between the predictor variables, precipitating variable and the decision to drop out. Whitemarsh's model was successful in identifying the patterns and the relevance of ICT schools students. The rationale for adapting Whitemarsh's model was based on the fact that the study was conducted within the Nigeria where all the schools share almost similar social life environment. Two categories of variables are used to guide the framework for this study, they include the expecting and triggering variables (causing variable) (Ballantine and Hammerick, 2009). The major components of the overall conceptual framework are summarized in below conceptual framework.

\begin{tabular}{|l|l|}
\hline $\begin{array}{l}\text { Causing variable } \\
\text { i. Outbreak of pandemic } \\
\text { ii. Initiation of distance learning } \\
\text { iii. Technological incline }\end{array}$ & $\begin{array}{l}\text { Effect (outcome) } \\
\text { i. low academic development } \\
\text { ii. not meeting up with world fasting } \\
\text { growing communication technology }\end{array}$ \\
\hline
\end{tabular}

(Source: research survey, 2020)

ICTs propose special opportunities to quicken growth and increase innovation in every local setting, thereby permitting individuals and institutions to interact more efficiently with the global economy and the wider world. But to realize their potential, technologies must be part of a mix of productive changes and supporting capabilities. Resources must be matched by inventiveness combined with other initiatives by local leaders, educators and entrepreneurs to achieve individual and institutional purposes. Education has been identified as one of the public sectors most shaped by technological developments (Kozma, 2005). The improvement of educational systems and increased educational attainment are primary to countries' preparation for global, technology-based changes in all sectors

\section{RESEARCH METHODOLOGY}

Research Design

According to Owusu-Bempah (2017), research design is the approach for study and the plan by which the strategy 
is to be carried out specifying the methods and the technique for the data collection, measurement, and analysis of data. This study design was descriptive survey design. This is a method of collecting information by interviewing and administering a questionnaire to a sample of individuals. This type of design was also useful when collecting information about people's attitudes, opinions, and habits.

\section{The Study Area Description}

Owerri is the capital of Imo State, Nigeria. It has an area of $58 \mathrm{~km}^{2}$ and a population of 127,213 according to the 2006 census. The postal code of the area is 460. Owerri city sits at the intersection of roads from Port Harcourt, Onitsha, Aba, Orlu, Okigwe and Umuahia. It is also the trade center for palm products, corn (maize), yams and cassava (manioc). Eke Ukwu Owere market is the main market in Owerri Municipal. It is specifically in South Eastern Nigeria. It lies between geographic co-ordinates of latitude $4^{\circ} 45$ and $7^{\circ} 15, ' \mathrm{~N}$ and longitude of $6^{\circ} 50$ ' $\mathrm{E}$ with an area of around 5,100sq km (Imo State Government, 2010). The state has a common boundary with Abia state on the East, Anambra state on the North, and Rivers state on the South.

\section{Population of the study}

Population is an organization of people or things that a researcher has in mind from which one can acquire information and draw conclusion. The target population is that population to which a researcher wants to oversimplify the results of the study. The target population of this study included teachers, school students in selected secondary schools and universities from Owerri municipal of Imo state, Nigeria. The schools include Federal Government Girls College Owerri, Baptist secondary school, Boys model secondary school, Logos International Secondary School, Holy Rosary secondary school, Federal university of Technology Owerri and Imo state university Owerri. The samples were selected randomly from different classes, gender and ages in these different schools. The respondents were picked randomly from the above named schools in Owerri as shown in the table below:

Table 1: Names of school and number of correspondents each

\begin{tabular}{|l|l|c|c|}
\hline S/N & Names of Schools & Number of students & Percentage of students \\
\hline 1. & Federal Government girls college Owerri & 25 & 12.2 \\
\hline 2. & Baptist secondary school & 30 & 14.7 \\
\hline 3. & Boys model secondary school Owerri & 15 & 7.3 \\
\hline 4. & Logos International Secondary School & 10 & 4.8 \\
\hline 5. & Holy Rosary secondary school & 20 & 9.7 \\
\hline 6. & Federal university of Technology Owerri & 40 & 21.9 \\
\hline 7. & Imo state university Owerri & 45 & 9.7 \\
\hline 8. & Teachers/lectures & 20 & 100 \\
\hline & Total & 205 & \\
\hline
\end{tabular}

\section{Sample Size and Sampling Techniques}

Krejice and Morgan, (2011) define sample as a smaller group of subjects drawn from the population in which a researcher is interested in gaining information and drawing conclusion. Sampling techniques refers to the process of selecting the participant of the study as a sample from the population. All students both in private and public secondary schools and public universities as mentioned above in Owerri municipal constituted the population of the study, including teachers and lecturers; only two hundred (205) respondents constituted the sample for the study and this was possible through random sampling techniques. The study was carried out by the use of interviews and questionnaires.

\section{Instrument for data collection}

The research instruments used in this study were observation, interviews and questionnaires.

The questionnaires

They were designed using closed and open-ended questions. It was an appropriate instrument because all the respondents were learned and competent of answering the items written in simple English language. This is a type of research instrument that gathers data of a large sample. The items in the first section required demographic information about the respondents such as age, sex, class, school etc. The second part sought information on importance of ICT in academic development to a national pandemic in secondary schools in Owerri municipal Imo state.

\section{Interviewing}

An interview is described by Gillham (2000) as a conversation, usually between two people, in which one person (the interviewer) is seeking responses for a particular purpose from the other person (the interviewee). Marks, (2000) is more precise in saying that an interview is a form of discourse shaped and organized by the asking and answering of questions, thereby allowing the interviewer and interviewee to talk about the focus of the study, and it also leads to a discussion of thoughts and perceptions. Gillham (2000) says that the overwhelming power of the face-to-face interview is the "richness" of the communication that is feasible. According to Naylor and Sayed. (2014), in this type of research the interview is used as the dominant strategy of data collection, in combination 
with observation, document analysis or other techniques. In all these situations, the interview is used "to gather descriptive data in the subjects' own words so that the researcher can develop insights on how subjects interpret some piece of the world.

\section{Validity of the Study}

Validity is the extent to which the results acquired from the analysis of the data really represent the phenomenon under study. Validity is an erstwhile qualitative procedure test of the research instrument in attempting to establish how they are accurate, correct, true, and meaningful and right in enhancing the intended data for the study. A pilot study was carried out to help the researcher in documentation of items in the research instrument that might bring about equivocality in eliciting the significant information. The items which were found to be abstruse in eliciting the relevant information were reconstructed.

\section{Reliability of the Study}

Reliability of a research instrument is a measure of the amount to which the instrument give up regular data after repeated examinations. Reliability of a questionnaire is concerned with the constancy of responses to the researchers' questions. Responses of each question in the questionnaire were associated with those of other questions in the questionnaire. A few questionnaires were given to a few respondents before the real study to determine whether the questions were understood by the respondents.

\section{Pilot Study}

Before data collection, the questionnaires were pre-tested to guarantee their validity and reliability. The significance of the items to the objectives of the study were evaluated to ensure comprehensive context coverage. The set of questionnaires were administered to a sample of 5 persons in one of the communities which were not included in the sample. The following areas were contemplated: the clearness of instruction on the questionnaires, the simplicity and appropriateness of the language used, the length and time taken by each respondent to complete the questionnaire.

\section{Administration of primary data}

This study was conducted with the goal of examining ICT in national pandemic, the hope for academic development in schools. Part one deal with the demographic variables of the respondents. Part two of the questionnaire deal with the importance of ICT in schools during the national pandemic, the respondent are meant to choose from the scaling options. Also, personal interviews was adopted to write down should incase the individual cannot write expressly.

\section{Method of data analysis}

The basis of data is primary and secondary. The primary data collected from the source is inspected and edited. Data analysis was achieved by means of descriptive analysis. The data collected was analyzed using simple statistics. Data analysis was based on a thorough examination of the field notes, on observations made, and on responses of each participant observed and interviewed. The researcher used the continuous comparative method i.e. qualitatively comparing and contrasting each topic and category to determine the distinctive characteristics of each. The questionnaires were tested for completeness, accuracy of information and uniformity. The questionnaires were checked to see if there were mistakes and lapses, adequate information and legibility and appropriate responses.

\section{Instrument of Data Analysis}

All the information from the questionnaire was entered into the Statistical Package for the Social Sciences (SPSS) Version 16.0. It was used to generate descriptive statistics. The interpretation of the descriptive statistics made it possible to make suitable inferences in terms of their effects on students' academic performance. With regard to the analysis of the semi-structured interview data, the qualitative data was used to clarify the quantitative responses.

\section{RESULTS AND DISCUSSION}

\section{Characteristics of the Respondents}

The figure 1 below showed the number of respondents with respect to their sex and ages. According to the results, it was revealed that majority of respondents $132(64.4 \%)$ were females and the remaining $73(35.6 \%)$ were males. This implies that gender was considered in selecting respondents so as to get consistent information regarding the relevance of ICT from both sexes. According to the result it was revealed that the majority of the respondents 73 (36\%) aged between 16-20 years, followed by 61 (30\%) whose age ranged between 10-15 years while 51 (26\%) their age ranged between 20-25 years and the remaining $17(8 \%)$ ranged for 26 years above. This implied that respondents were mature enough to make judgments in all aspects of life. Also, all the respondent were able to write and also read, with that they are all educated, despite most of them are still in secondary school but have the ability to read and write. 

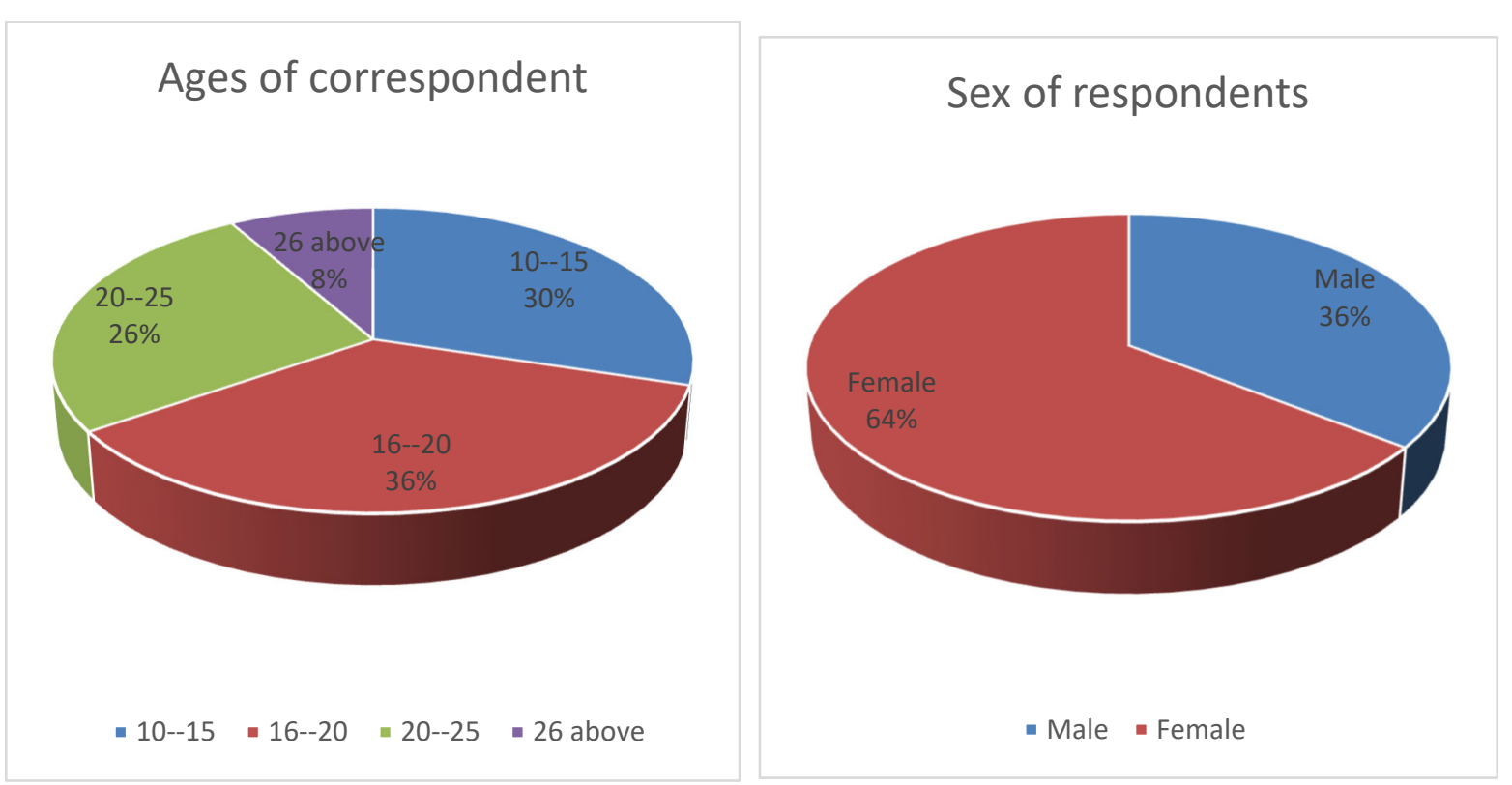

Figure 1: Age and sex of Respondent (Source: Field survey, 2020)

\section{General view on the relevance of ICT}

From the result obtained from this study as shown in figure 2, presents the response by the respondents on their awareness on the relevance of ICT during national pandemic on student's academic performance. The questionnaires were administered by the researcher to 205 respondents as seen above. The question was: Are there hope for academic through ICT in national pandemic? All the respondents indicated that ICT is the only hope for distance learning during national pandemic for academic development.

\section{ICT the hope for academic development}

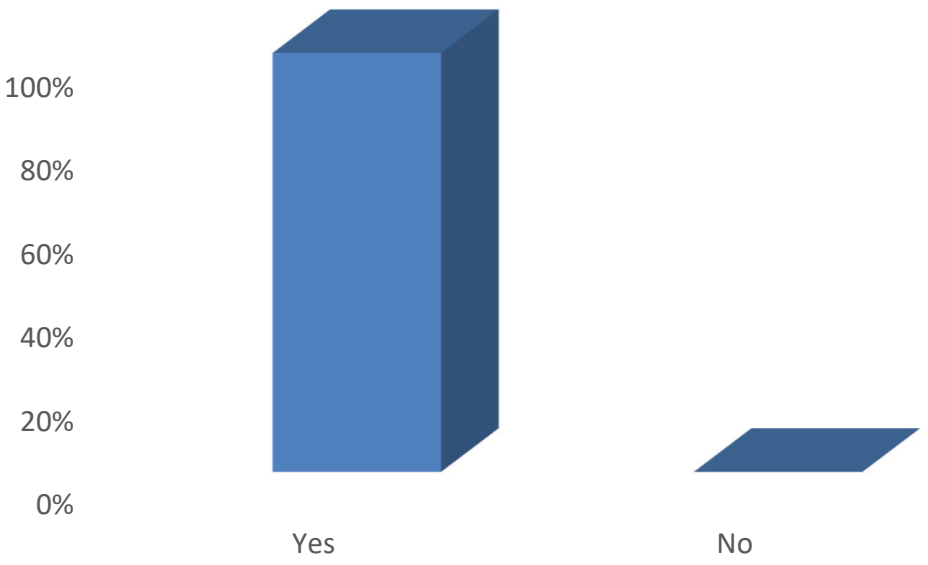

Figure 2: Awareness on the relevance of ICT in education during national pandemic (Source: Field survey, 2020)

\section{Frequently used online teaching Apps}

The researcher went further to ask the students the regular and frequently used ICT software their teachers and lecturers uses to communicate with them during the national pandemic and why they are being used. The data obtained had shown that whatsapp (50\%) had the highest used by the students and from the personal interview with the respondent, they testified that the use of whatsapp is less expensive and it does not require strong network. On the use, one of the students had this to say:

Chinazo in Imo state university, had this to say: whatsapp is the app that can be easily assessed by us students and its not data consuming as other communication apps. Also, it can easily record voice notes and we can easily have asses to the lecturers' voice notes any time we come

Another said: on line. 
Ebuka had this to say: leaning from whatsapp software is better or me, our teachers only record their voce notes and send to us, they don't even see us and I like it. I think it saves battery too.

Google classroom (24\%) was the second in use by the students and teachers. From the interview sessions had with some of the students, they testified that Google classroom can also do some of the functions that whatsapp can do and also it doesn't consume data.

On the use, one of the students had this to say:

Chizzy in Jss 2 had this to say: we do online classes and we use Google classroom, we can ask questions in the class and copy note as well. Our teacher always connect before us but most times network can interrupt the class a little.

The results also showed that Microsoft team had $12 \%$ respondents for those using it, zoom has $10 \%$, Skype had $4 \%$ and the respondents stated clearly that they have not tried using slack. The summation of the data obtained from the communication apps that aids distance learning are summarized in figure 3 below.

\section{Communication Apps mostly used}

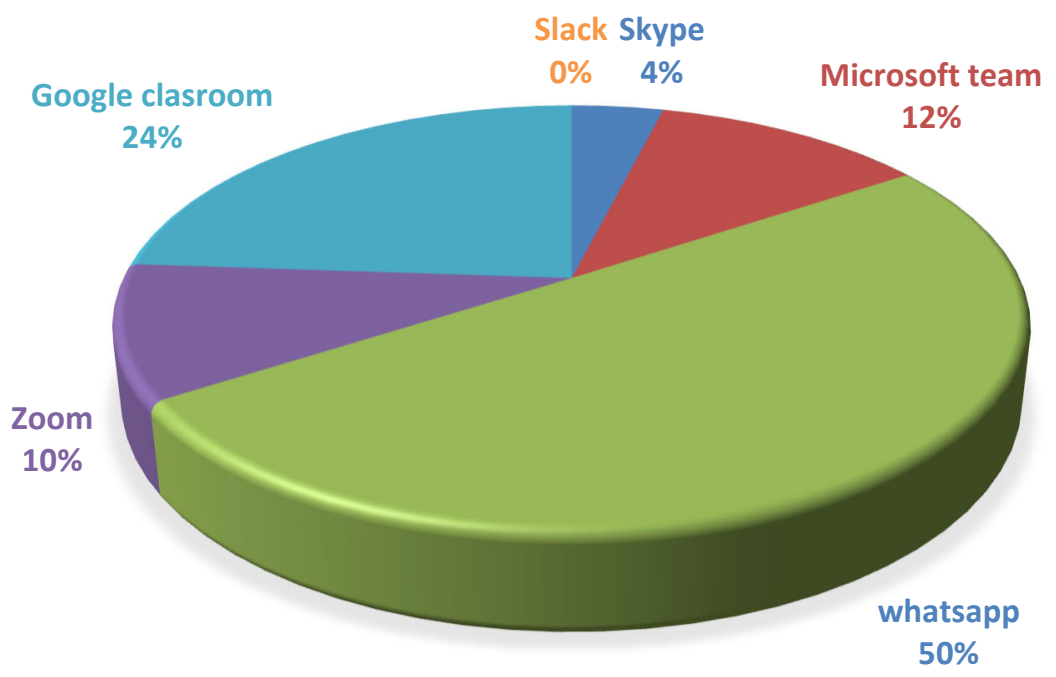

Figure 3: Frequently used teaching Apps by teachers

\section{Summarized general research questionnaire}

The part of the questionnaires and interviews that the researcher used for this section are summarized into ten (10) items structured on a modified 4-point ticker's scale of "SA (Strongly agree)", "A (Agree)", "D (Disagree)", and "SD (Strongly disagree)" to elicit information about the research questions with some statistical techniques; min, $\max$ and mean \pm standard deviation. The researcher monitored the questions to ensure accuracy in answering each question and the summary are shown in table 2.

Table 2: Use of Social Media in the Academic Setting

\begin{tabular}{|l|l|l|l|l|l|l|l|}
\hline Variable & SA (n) & A, \% (n) & D \% (n) & SD\% (n) & Min & Max & Mean \pm Std \\
\hline Enables class discussion & $28.9(58)$ & $27.8(57)$ & $26.4(54)$ & $17.5(36)$ & 36 & 58 & 10.31 \\
\hline Distribution of research activities & $40.9(84)$ & $29.7(61)$ & $17.1(35)$ & $12.2(25)$ & 25 & 84 & 26.58 \\
\hline Permits online assignments & $57.5(118)$ & $36.5(75)$ & $4.9(10)$ & $0.9(2)$ & 2 & 118 & 55.21 \\
\hline Gives room for immediate feedback & $17.5(36)$ & $21.9(45)$ & $38.5(79)$ & $25.9(53)$ & 36 & 79 & 18.51 \\
\hline Active learning & $15.1(31)$ & $27.3(56)$ & $30.2(62)$ & $27.3(56)$ & 31 & 62 & 13.79 \\
\hline Communicate high expectation & $27.8(57)$ & $32.2(66)$ & $32.6(67)$ & $20(41)$ & 41 & 67 & 12.03 \\
\hline Emphasize time on task & $30.7(63)$ & $37.5(77)$ & $44.2(46)$ & $9.3(19)$ & 19 & 77 & 24.95 \\
\hline Creating quizzes and exams & $59.0(121)$ & $27.8(57)$ & $9.2(19)$ & $3.9(8)$ & 8 & 121 & 51.01 \\
\hline Encourage practical subjects and courses & $4.3(9)$ & $8.3(17)$ & $31.7(65)$ & $55.6(114)$ & 9 & 114 & 48.59 \\
\hline Encourage exams without malpractice & $2.9(6)$ & $12.1(25)$ & $31.2(64)$ & $53.2(109)$ & 6 & 109 & 45.58 \\
\hline
\end{tabular}

Form the results obtained and as seen in table 2, $58(28.9 \%)$ respondents strongly agreed that the use of ICT for distance learning encourages class discussion, 57 (27.8\%) respondents agreed to that, 54 (56.4\%) respondents disagreed on the use of ICT for effective class discussion while $36(17.5 \%)$ strongly disagreed to that, this is in line with the results obtained by Ashish et al., (2013), who identified the use of ICT for distance learning for both adult learning and normal school standards. Students find it fun to do online research with their mates, they find it interesting since they will in the other hand discuss and chat about their selves. From the data summarized in table $2,84(40.9 \%)$ strongly agreed on the distribution of research activities using ICT, followed by $61(29.7 \%)$ which was agreed, next by 35 (17.1\%) which disagreed with that and lastly $25(12.2 \%)$ which strongly disagreed. Cholin, 
(2005), researched on the Study of the application of information technology for effective access to resources and Chandra and Patkar, (2007) researched on the use of ICT as catalyst for enriching learning. They found out that the use of ICT encourage research activities since all information needed for any form of online research is found on the internet. Majority of the respondents strongly agreed that ICT permits online assignment. Communicating high expectations, emphasizing time on task, creating quizzes and exams, immediate feedback mechanisms are major principles underlying teaching. Active learning had the highest percentage of disagree $62(30.2 \%)$ while 31 $(15.1 \%)$ strongly agreed on the encouragement of the use of ICT for active learning. $6(2.9 \%)$ respondents strongly agreed on the encouragement of exam without malpractice using ICT, 25 (12.1\%) agreed, 64 (31.2\%) disagreed and $109(53.2 \%)$ strongly disagreed. This is also in agreement with the findings of Kozma, (2005) also noted that ICT aids easy access to the other materials since there is no proper supervision since the students will have access to other materials in their various homes.

\section{Conclusion}

Based on the widespread usage of ICTs in education the need seemed to unstitch the myth that surrounds the use of information and communication technology (ICT) as an aid to teaching and learning for all forms of distance learning amidst of national pandemic, and the impact it has on students' academic performance. ICTs are said to help expand approach to education, support the relevance of education to the progressively digital workplace, and raise educational quality. However, the experience of introducing different ICTs on the online learning platforms and other educational settings all over the world suggests that the full comprehension of the potential educational benefits of ICT in developing academic achievement of students during national pandemic. The results indicate that ICT approaches has been the only hope for academic activities during the national pandemic. Collaboration on research and configuration of online exams to avoid examination malpractice should be handled and strategize as students testified easy access to other materials online during examination and other evaluation. Reasons for these findings could be a lack of understanding of the potential uses of these tools in the academic and research setting.

\section{Conflict of interest}

The authors declare that there were no conflict of interest during and after this reseacrh work and processes.

\section{References}

Ashish, J. M. D., Jane M. P. H., Sergio, C., Douglas, M. P., Kate, T. M. and Atul, R. M. S. (2013). The Role of Information and Communication Technology in Community Outreach, Academic and Research Collaboration, and Education and Support Services (IT-CARES). Perspect Health Inf Manag. 10(Fall): 11

Ballantine, J. H. and Hammerick, F. M. (2009). The Sociology of Education: A systematic Analysis, 6th ed. London: Pearson Publishers

Bhattacharya, I. and Sharma, K. (2007), 'India in the knowledge economy - an electronic paradigm', International Journal of Educational Management Vol. 21 No. 6, Pp. 543- 568.

Brown, T. H. (2005). Towards a model for m-Learning in Africa. International Journal on ELearning, 4(3), 299316.

Chandra, S. and Patkar, V. (2007), 'ICTS: A catalyst for enriching the learning process and library services in India', The International Information \& Library Review Vol. 39, No. (1), Pp; 1-11.

Cholin, V. S. (2005), 'Study of the application of information technology for effective access to resources in Indian university libraries', The International Information \& Library Review Vol.37,No.(3), 189-197.

Daniels, J. S. (2002) "Foreword" in Information and Communication Technology in Education-A Curriculum for Schools and Programme for Teacher Development. Paris: UNESCO.

Daniels, J. S. (2002). Foreword. In J. Anderson \& T. van Weert (Eds.), Information and Communication Technology in Education: A Curriculum for Schools and Programme for Teacher Development. Paris: UNESCO.

Gaskell, A. and Tait, A. (Eds.). (2003). The future of open and distance learning. Proceedings of the 10th International Conference on Open and Distance Learning. Cambridge: The Open University in the East of England.

Gillham, B. (2000) Case Study Research Methods. New York: Canadian Journal of Education, 29, $2410-435$.

Gostin, L. O. and Friedman, E. A. (2015). A retrospective and prospective analysis of the west African Ebola virus disease epidemic: robust national health systems at the foundation and an empowered WHO at the apex. The Lancet, 385(9980), 1902-1909.

Gostin, L. O., Tomori, O., Wibulpolprasert, S., Jha, A. K., Frenk, J., Moon, S., . . Dzau, V. J. (2016). Toward a Common Secure Future: Four Global Commissions in the Wake of Ebola. PLoS Med, 13(5), e1002042.

Grace, J. and Kenny, C. (2003). A short review of information and communication technologies and basic education in LDCs - what is useful, what is sustainable? International Journal of Educational Development, 
23(6), 627-636.

Harris, S. (2002). Innovative pedagogical practices using ICT in schools in England. Journal of Computer Assisted Learning, No. 18, Pp;449-458.

Harris, S. S. (2000). A Dictionary of Epidemiology, Fourth Edition.pdf.

Hepp, K. P., Hinostroza, S. E., Laval, M. E. and Rehbein, L. F. (2004) "Technology in Schools: Education, ICT and the Knowledge Society "OECD. Available: wwwl.worldbank.org/education/pdf/ICT_report_oct04a.pdf.

Kozma, R. (2005), 'National Policies That Connect ICT-Based Education Reform To Economic And Social Development', Human Technology Vol.1, No. (2), Pp; 117-156.

Kozma, R. B. (2005). National policies that connect ICT-based education reform to economic and social development. An Interdisciplinary Journal on Humans in ICT Environments, 1(2), 117-156.

Krejice, R. K and Morgan, D. W (2011). Determine Sample Size for Research Activities Educational and Psychology Measurement, 30, 607-610

Leach, J. (2005). Do new information and communication technologies have a role to play in achieving quality professional development for teachers in the global south? Curriculum Journal, 16(3), 293-329.

Lim, C. P. and Chai, C. S. (2004). An activity-theoretical approach to research of ICT integration in Singapore schools: Orienting activities and learner autonomy', Computers \& Education Vol. 43, No. (3), Pp; 215--236.

Liverpool, L. S. O. (2002). Information and communication technology in teacher education. In Teacher Education in Nigeria: Past Present and Future - Proceedings of the First Teachers' Summit. Kaduna: NTI.

Marks, H. M. (2000). Student engagement in instructional activity: Patterns in the elementary, middle, and high school years. American Educational Research Journal, 37(1), 153-184:

Maurice, J. (2016). Cost of protection against pandemics is small. The Lancet, 387(10016), e12.

Mooij, T. (2007), 'Design of educational and ICT conditions to integrate differences in learning: Contextual learning theory and a first transformation step in early education', Computers in Human Behaviour Vol. 23, No. (3), Pp; 1499-1530.

Moon, B. (2007). Research analysis: Attracting, developing and retaining effective teachers: A global overview of current policies and practices. Paris: UNESCO.

Morens, D. M., Folkers, G. K. and Fauci, A. S. (2009). What is a pandemic? J Infect Dis, 200(7), 1018-1021. Nabarro, D. and Wannous, C. (2016). The Links Between Public and Ecosystem Health in Light of the Recent Ebola Outbreaks and Pandemic Emergence. EcoHealth, 1-3.

Naylor, R. and Sayed, Y. (2014). Teacher quality: Evidence review. Office of Development Effectiveness: International Journal of Educational 4(2):18-32.

Owusu-Bempah, K. (2017). Children and teachers: Socio-genealogical connectedness perspective. New York, NY: Routledge.

Pelgrum, W. J. (2002). The effectiveness of ICT in schools: Current trends and future prospects discussion paper. Paper presented at the OECD Japan Seminar: Teachers, teacher policies and ICT.

Pelgrum, W. J. and Law, N. (2003) "ICT in Education around the World: Trends, Problems and Prospects"UNESCO-International Institute for Educational Planning. Available: www.worldcatlibraries.org/wcpa/ow/02d077080fcf3210a19afeb4da09e526.html.

Perraton, H., Robinson, B. and Creed, C. (2001). Teacher education through distance learning: technology, curriculum, cost, evaluation. Paris: UNESCO.

Rewar, S., Mirdha, D. and Rewar, P. (2015). Treatment and Prevention of Pandemic H1N1 Influenza. Annals of Global Health, 81(5), 645-653.

Sanyal, B. C. (2001), 'New functions of higher education and ICT to achieve education for all', Paper prepared for the Expert Roundtable on University and Technology-for- Literacy and Education Partnership in Developing Countries, International Institute for Educational Planning, UNESCO, September 10 to 12, Paris.

Sharma, R. (2003), 'Barriers in Using Technology for Education in Developing Countries', IEEE0-7803-77249103.Singapore schools', Computers \& Education Vol .41, No.(1),Pp; 49-63.

Tella, A., Tella, A., Toyobo, O. M., Adika, L. O. and Adeyinka, A. A. (2007). An Assessment of Secondary School Teachers Uses of ICTs: Implications for Further Development of ICT's Use in Nigerian Secondary Schools. Online Submission, 6(3).

UNESCO (2002) Information and Communication Technology in Education-A Curriculum for Schools and Programme for Teacher Development. Paris: UNESCO.

UNESCO, (2002),'Open And Distance Learning Trends, Policy And Strategy Considerations',14 UNESCO.

UNESCO. (2008). ICT Competency Standards for Teachers - Implementation Guidelines, Version 1.0. Retrieved 28th September 2009. Retrieved from http://www.unesco.org/en/competency-standards-teachers

Uwaifo, V. O. (2012). The effects of family structure on the academic performance of Nigerian university students. Global Journal of Hu-man Social Science, 12, 53-56.

Whitemarsh, S. (2008). Elementary School Teachers' Perceptions of Divorce. Unpublished master's thesis, University of Wisconsin-Eau Claire, Eau Claire, WI. Journal of Adolescence, 27, 351-362. 
WHO. (2011a). The classical definition of a pandemic is not elusive. Bull World Health Organ, 89(7), 540-541.

Yusuf, M.O. (2005). Information and communication education: Analyzing the Nigerian national policy for information technology. International Education Journal Vol. 6 No. (3), Pp; 316-321. 